\title{
Partial replacement of soybean meal with different protein sources in piglet feed during the nursery phase
}

\author{
Jansller Luiz Genova ${ }^{1, *}$, Paulo Levi de Oliveira Carvalho ${ }^{1, *}$, Newton Tavares Escocard de Oliveira', \\ Aparecida da Costa Oliveira', Franz Dias Gois ${ }^{2}$, Davi Elias de Sá e Castro ${ }^{1}$, Fábio Nicory Costa Souza ${ }^{3}$, \\ Heloíse Trautenmüller', Liliana Bury de Azevedo dos Santos ${ }^{3}$, and Isabela Ferreira Leal ${ }^{1}$
}

\footnotetext{
* Corresponding Authors:

Jansller Luiz Genova

Tel: +55-45-9844-4916, Fax: +55-45-3284-7912,

E-mail: jansllerg@gmail.com

Paulo Levi de Oliveira Carvalho

Tel: +55-45-9851-9262, Fax: +55-45-3284-7942,

E-mail: paulolevi@yahoo.com.br
}

'Animal Science Department, State University of Western Paraná, Marechal Cândido Rondon, PR 85960-000, Brazil

${ }^{2}$ Animal Science Department, State University of Santa

Cruz, Ilhéus, BA 45662-900, Brazi

${ }^{3}$ Animal Science Department, Federal University of

Bahia, Salvador, BA 40170-110, Brazil

ORCID

Jansller Luiz Genova

https://orcid.org/0000-0002-8000-2166

Paulo Levi de Oliveira Carvalho

https://orcid.org/0000-0001-9273-3209

Newton Tavares Escocard de Oliveira

https://orcid.org/0000-0003-3347-9399

Aparecida da Costa Oliveira

https://orcid.org/0000-0003-4880-7551

Franz Dias Gois

https://orcid.org/0000-0003-4189-7523

Davi Elias de Sá e Castro

https://orcid.org/0000-0001-7330-5372

Fábio Nicory Costa Souza

https://orcid.org/0000-0002-9077-4557

Heloíse Trautenmüller

https://orcid.org/0000-0002-9546-892X

Liliana Bury de Azevedo dos Santos

https://orcid.org/0000-0002-6203-6274

Isabela Ferreira Leal

https://orcid.org/0000-0002-1810-2553

Submitted Oct 14, 2017; Revised Jan 5, 2018; Accepted Oct 16, 2018
Objective: Evaluate the partial replacement of soybean meal with different protein sources in piglet feed during the nursery phase in terms of digestibility of feed, nitrogen balance, growth performance and blood parameters.

Methods: Experiment I involved 24 crossbred entire male pigs with an initial body weight (BW) of $18.28 \pm 0.7 \mathrm{~kg}$ and used a randomized complete block design consisting of 3 treatments (fish meal, FM; soybean protein concentrate, SPC; and soybean meal, SBM) and 8 replicates, with 1 pig per experimental unit. Experiment II involved 1,843 crossbred male and female pigs with an initial BW of $6.79 \pm 0.90 \mathrm{~kg}$ and was based on a completely randomized design with a $2 \times 3$ factorial arrangement ( 2 sexes and 3 protein sources) and 13 replicates.

Results: The results of Exp. I indicate effects $(\mathrm{p}<0.05)$ of dietary protein sources on digestible protein (FM, 17.84\%; SPC, 16.72\%, and SBM, 18.13\%) and on total nitrogen excretion (TNE, $\mathrm{g} / \mathrm{kg} \mathrm{BW} \mathrm{BW}^{0.75} / \mathrm{d}$ ) in which pigs fed with SBM-based feed had TNE values that were $5.36 \%$ and $3.72 \%$ greater than SPC and FM, respectively. In the Exp. II, there was difference $(\mathrm{p}<0.01)$ between sexes in the pre-starter I and starter phases, and total period in average daily feed intake (ADFI), which were greater in females, and between the protein sources, ADFI, final weight and daily weight gain. For urea in the pre-starter II and starter phases and glucose in the pre-starter II phase, there was a difference $(\mathrm{p}<0.05)$ between protein sources and between sexes, in starter phase in urea concentrations (females: $57.11 \mathrm{mg} / \mathrm{dL}$ and males: $50.60 \mathrm{mg} / \mathrm{dL}$ ). Conclusion: The use of SBM as only protein source influences larger TNE (g/kg BW $\left.{ }^{0.75} / \mathrm{d}\right)$, reduces the growth performance of piglets and increases plasma urea concentrations in prestarter II phase.

Keywords: Nitrogen Balance; Growth Performance; Fish Meal; Blood Parameters; Soybean Protein Concentrate; Swine

\section{INTRODUCTION}

Weaning is considered the most critical phase in the life of a piglet because it is associated with numerous stress factors, such as loss of contact with the mother, environmental and dietary changes, and the establishment of a new social hierarchy. During this transitional period reduced feed intake, high morbidity and susceptibility to enteric infections are observed, considering that the development of the gastrointestinal tract and microbiota, and undeveloped active immunity are related to the growth performance of animals [1].

In this context, developments in animal nutrition provide information for the formulation of balanced diets, through better evaluation of ingredients and knowledge of the nutritional requirements of different phases of breeding. With the intensive production of pigs there is a need to search for new nutritional ingredients and strategies that contribute to the efficient 
functioning of the physiology of the animals and promote good growth performance.

It is important for animal nutrition to study ingredients that minimize production costs and, while at the same time promote health for piglets. The questions for nutritionists are the protein concentrations in nursery period, the sources of protein to formulate feeds for weaned piglets [2] and the digestibility and palatability of the feed. Therefore, soybean meal (SBM) is used in feeds as a primary source of vegetable protein. In contrast, piglet feeds are complex and, notably, make use of different protein sources that minimize the decreasing performance curve which occurs in the first days after weaning.

Studies evaluating the use of protein sources in the nutrition of piglets have only recently been reported and include experiments with soybean protein concentrate (SPC) and SBM $[3,4]$, fish meal (FM) $[5,6]$, spray-dried animal plasma and whole egg [7].

In this context, the goal of this study was to investigate the partial replacement of SBM with different sources of protein in piglet feed and their effect on feed digestibility, nitrogen balance, blood parameters and growth performance.

\section{MATERIALS AND METHODS}

Two experiments were conducted. Experiment I was carried out in the Swine Sector of the Experimental Station Nucleus of the State University of Western Paraná - Unioeste, Campus of Marechal Cândido Rondon, Paraná. Experiment II was carried out in a commercial grange, located in the city of Marechal Cândido Rondon, PR.

\section{Animal care}

All animal-based procedures and the protocol for animal use are in approval by the Animal Care and Use Committee of State University of Western Paraná - Unioeste.

\section{Experimental design, animals, housing and diets}

A total of 24 crossbred entire male pigs, with an initial average body weight (BW) of $18.17 \pm 0.7 \mathrm{~kg}$, were used in a metabolism study and were distributed in a randomized complete block design with 3 treatments (protein sources) and 8 replicates, totaling 24 experimental units. The blocks were based on initial BW.

The animals were housed individually in metabolic cages similar to those described previously [8], where they remained for 12 days, 7 days for acclimation to cages and feed, and 5 days for collection of feces and urine.

During the acclimation phase, the animals received two meals per day, provided at 08:00 and at 15:00. The total daily amount of feed provided during the collection period was determined from the acclimation period, based on the animals' voluntary consumption and metabolic weight $\left(\mathrm{BW}^{0.75}\right)$. The feed was moistened with water ( $20 \%$ by total weight of feed) to avoid waste, reduce powdery properties and improve palatability. After each meal, water was supplied through a feeder in the proportion of $3 \mathrm{~mL} / \mathrm{g}$ of feed consumed; the quantity was calculated for each experimental unit to avoid excess water consumption.

A data logger, with a capacity of 24 measurements per $\mathrm{d}$, was used to measure the ambient temperature $\left({ }^{\circ} \mathrm{C}\right)$ and relative humidity during the experimental period. The minimum recorded temperature of the internal environment was $21^{\circ} \mathrm{C}$ $\pm 4.95^{\circ} \mathrm{C}$ and the maximum was $23^{\circ} \mathrm{C} \pm 5.16^{\circ} \mathrm{C}$.

The experimental feeds were composed of: control diet containing soybean meal as a conventional protein source (SBM); control diet with the inclusion of fish meal $(\mathrm{SBM}+\mathrm{FM})$; and control diet with the inclusion of SPC (SBM+SPC; Table 1). The feed was provided by a local company and the guaranteed concentrations of nutrients were close to the reported concentrations [9]. The physicochemical composition values of all tested ingredients were determined by the NIRS DS2500 F analyzer (Nutrifarma, Maripá, PR, Brazil). The results are close to those found in the Brazilian Tables for Poultry and Swine: feed composition and nutritional requirements [9]. Four types of feed were provided for all piglet growth phases involved in the current study: post-weaning, pre-starter I, prestarter II, and starter (Table 2).

For the performance trial (Exp. 2), 1,843 crossbreed piglets (998 entire males and 845 females) were used, aged 21 days with an average initial BW of $6.79 \pm 0.90 \mathrm{~kg}$. Animals were distributed in a completely randomized design, in a $2 \times 3$ factorial arrangement ( 2 sexes and 3 protein sources) with 13 replicates of 46 to 53 animals per experimental unit. All treatments had the same number of replications, that is, experimental units.

The experimental diets were same used in Exp. 1. The animals were identified with numbered ear tags and housed in suspended nursery stalls $\left(14 \mathrm{~m}^{2}\right)$, with polyethylene plastic flooring, equipped with pacifier type drinking fountains and semi-automatic center feeders, and located in masonry shed with concrete flooring, ceramic roof tiles and a wood-furnace heating system. Feed and water were provided ad libitum throughout the experimental period.

A data logger, with a capacity of 24 measurements per day, was used to measure the ambient temperature $\left({ }^{\circ} \mathrm{C}\right)$ and relative humidity during the experimental period. The minimum recorded temperature of the internal environment was $15^{\circ} \mathrm{C} \pm$ $5.73^{\circ} \mathrm{C}$ and the maximum was $16^{\circ} \mathrm{C} \pm 5.78^{\circ} \mathrm{C}$.

In Exp. 2, blood parameters were determined at the end of the pre-starter II and starter phases in 231 of the total animals tested. Blood samples were collected via the vena cava, using $0.70 \times 30 \mathrm{~mm}$ and $0.80 \times 40 \mathrm{~mm}$ gauge needles, into $5-\mathrm{mL}$ test tubes containing urea anticoagulant (ethylenediaminetetraacetic acid) and glucose (sodium fluoride), according to 
Table 1. Centesimal and chemical composition of experimental diets for piglets in nursery phase (as-fed basis)

\begin{tabular}{|c|c|c|c|c|c|c|c|c|c|c|c|c|}
\hline \multirow{4}{*}{ Items } & \multicolumn{12}{|c|}{ Protein sources } \\
\hline & \multicolumn{4}{|c|}{$\mathrm{SBM}+\mathrm{FM}$} & \multicolumn{4}{|c|}{$\mathrm{SBM}+\mathrm{SPC}$} & \multicolumn{4}{|c|}{ SBM } \\
\hline & \multicolumn{12}{|c|}{ Experimental phases $^{1)}(6.00$ to $22.00 \mathrm{~kg})$} \\
\hline & PW & PI & PII & $\mathrm{S}$ & PW & PI & PII & $S$ & PW & PI & PII & $S$ \\
\hline Corn & 38.0 & 49.2 & 55.2 & 59.8 & 38.0 & 49.2 & 55.2 & 59.8 & 38.4 & 47.8 & 54.0 & 59.3 \\
\hline Soybean meal $45.22 \%$ & 9.0 & 18.0 & 25.0 & 30.0 & 9.0 & 18.0 & 25.0 & 30.0 & 12.6 & 22.9 & 29.2 & 32.0 \\
\hline Soybean oil & 4.0 & 3.4 & 2.8 & 2.7 & 4.0 & 3.4 & 2.8 & 2.7 & 4.0 & 3.4 & 2.8 & 2.7 \\
\hline Fish meal & 4.0 & 3.5 & 3.0 & 1.5 & - & - & - & - & - & - & - & - \\
\hline SPC & - & - & - & - & 4.0 & 3.5 & 3.0 & 1.5 & - & - & - & - \\
\hline Nucleus $^{2)}$ & 45.0 & 26.0 & 14.0 & 6.0 & 45.0 & 26.0 & 14.0 & 6.0 & 45.0 & 26.0 & 14.0 & 6.0 \\
\hline Total (\%) & 100.0 & 100.0 & 100.0 & 100.0 & 100.0 & 100.0 & 100.0 & 100.0 & 100.0 & 100.0 & 100.0 & 100.0 \\
\hline \multicolumn{13}{|l|}{ Calculated composition } \\
\hline Crude protein (\%) & 18.2 & 18.5 & 19.1 & 20.1 & 18.2 & 18.5 & 19.1 & 20.0 & 18.2 & 18.4 & 19.0 & 20.0 \\
\hline Lactose (\%) & 14.7 & 7.1 & 2.6 & - & 14.7 & 7.1 & 2.6 & - & 14.7 & 7.1 & 2.6 & - \\
\hline ME (kcal/kg) & 3,726 & 3,555 & 3,427 & 3,401 & 3,708 & 3,556 & 3,416 & 3,400 & 3,329 & 3,501 & 3,506 & 3,497 \\
\hline Lysine (\%) & 1.417 & 1.372 & 1.345 & 1.321 & 1.416 & 1.373 & 1.346 & 1.320 & 1.416 & 1.374 & 1.347 & 1.320 \\
\hline Methionine (\%) & 0.52 & 0.52 & 0.52 & 0.48 & 0.51 & 0.51 & 0.51 & 0.48 & 0.52 & 0.52 & 0.52 & 0.48 \\
\hline Calcium (\%) & 0.48 & 0.55 & 0.70 & 0.72 & 0.39 & 0.38 & 0.70 & 0.61 & 0.39 & 0.38 & 0.70 & 0.70 \\
\hline STTD phosphorus (\%) & 0.45 & 0.39 & 0.35 & 0.34 & 0.43 & 0.37 & 0.34 & 0.33 & 0.44 & 0.38 & 0.34 & 0.33 \\
\hline Sodium (\%) & 0.33 & 0.28 & 0.23 & 0.24 & 0.30 & 0.25 & 0.20 & 0.22 & 0.30 & 0.25 & 0.20 & 0.22 \\
\hline
\end{tabular}

SBM, soybean meal; FM, fish meal; SPC, soybean protein concentrate; ME, metabolizable energy; STTD, standardized total tract digestible.

1) PW, post-weaning; PI and PII, pre-starter I and II; S, starter.

2) Composition per feed and phase: SBM+FM (\%): Mg monoxide $0.12,0.15,0.18,0.19 ; \mathrm{Cl}$ sulfate $0.67,0.52,0.42,0.40 ; \mathrm{K}$ iodate $1.05,0.89,0.80,0.79$ (mg/kg); Cu sulfate 4.5, 4.5, 154.5, 154.5; Organic Cu 117, 117, 4.5, 4.5; Fe sulfate 70; I 1.2; Mn sulfate 30.2; Org. Mn 10.1; Niacin 35.1; Sodium selenite 0.30; Zn oxide 2,500; Org. Zn 10.0; Vitamin $K_{3}$ 4.0; Vitamin $B_{1}$ 2.1; Vitamin $B_{2}$ 10.2; Vitamin $B_{6} 6.0$; Vitamin $B_{12} 0.04$; Folic acid 1.01; Pantothenic acid 19.9; Biotin 0.15; Choline chloride 1,347, 1,445, 1,421, 1,479; BHT 3.76; Ethoxyquin 15.0 (IU/kg); Vitamin A 14,100; Vitamin D 2,820; Vitamin E 80.3; SBM+SPC (\%): Cl sulfate 0.62, 0.48, 0.38, 0.39; K iodate 1.10, 0.94, 0.84, 0.80 (mg/kg): Choline chloride 1,245, 1,356, 1,343, 1,432; SBM (\%): Mg monoxide $0.13,0.15,0.18,0.19 ; \mathrm{Cl}$ sulfate $0.62,0.48,0.38,0.39 ; \mathrm{K}$ iodate $1.11,0.94,0.84,0.81$ (mg/ $\mathrm{kg}$ ): Choline chloride 1,281, 1,388, 1,370, 1,447. Values represent the amount of mineral or vitamin per phase PW, PI, PIl; S. Only the amount of chlorine sulfate, potassium iodate and choline chloride are different between the feeds, and magnesium monoxide for the SBM feed.

the technique previously described [10]. Blood samples were then sent to the Blood Parameters Laboratory of the State University of Western Paraná. The samples were centrifuged
(Centrilab digital centrifuge, Model 80-2B; Labingá, Maringá, PR, Brazil) at 3,000 $\mathrm{g}$ for $15 \mathrm{~min}$; the plasma was transferred to "Eppendorf" polyethylene tubes in duplicate, labelled and

Table 2. Nucleus composition ( $\mathrm{g} / \mathrm{kg}$ ) of experimental feeds for piglets in nursery phase (as-fed basis)

\begin{tabular}{|c|c|c|c|c|}
\hline Concentrations of warranty $(\mathrm{g} / \mathrm{kg})^{1)}$ & Post-weaning $^{2)}$ & Pre-starter $\left.\right|^{2)}$ & Pre-starter $\|^{2)}$ & Starter $^{2)}$ \\
\hline Crude protein (Min) & 186.00 & 280.00 & 260.00 & 270.00 \\
\hline Ether extract (Min) & 55.00 & 13.00 & 17.00 & 26.00 \\
\hline Mineral matter (Max) & 50.00 & 150.00 & 185.00 & 500.00 \\
\hline Calcium (Min to Max) & 3.00 to 5.00 & 1.30 to 1.50 & 20.0 to 40.0 & 100.00 to 140.00 \\
\hline Phosphorus (Min) & 4.50 & 10.00 & 16.00 & 35.00 \\
\hline Sodium (Min) & - & - & - & 35.00 \\
\hline Lysine (Min) & 15.00 & 32.00 & 40.00 & 55.00 \\
\hline Methionine (Min) & 5.85 & 15.00 & 22.00 & 37.00 \\
\hline Threonine (Min) & - & - & - & 28.00 \\
\hline Crude fiber (Max) & 14.00 & 7.00 & 5.00 & 8.00 \\
\hline Phytase unit/kg (Min) & 500.00 & - & - & 8.30 \\
\hline
\end{tabular}

1) Minimum and maximum values.

2) Basic composition of the nucleus, post-weaning: vegetable fatty acid (ACFA), acidifying additive, aromatizing additive, enzymatic additive, bentonite, biotin, calcium carbonate, choline chloride, sodium chloride, grape seed extract (polyphenols), phytase, dicalcium phosphate, soybean grain extruded, potassium iodate, L-lysine, DL-methionine, L-threonine, L-tryptophan, degummed soybean oil, zinc oxide, palatabilizant, calcium pantotenate, blood plasma, sodium selenite, whey powder, milk-sugar, cobalt sulfate, copper sulfate, iron sulfate, manganese sulphate, colistin sulfate; pre-starter I and II: same composition of PW, except for aromatizing additive, bentonite, grape seed extract, degummed soybean oil and milk-sugar; starter: same composition of Pre-starter I and II, except for enzymatic additive, soybean grain extruded, L-tryptophan, blood plasma and whey powder. 
stored in a freezer at $-5^{\circ} \mathrm{C}$ for further analysis. Plasma urea and glucose concentrations were determined using kits from ELITech (Clinical Systems; ELITech Latin America, Vitória, ES, Brazil).

\section{Sample collection and preparation}

In Exp. 1, the amount of feed supplied, feces and urine samples collection were conducted according to the methods previously described [11].

During the collection period, $1 \%$ of ferric oxide $\left(\mathrm{Fe}_{2} \mathrm{O}_{3}\right)$ was added to the feed to mark the beginning and end of fecal collection. Feces were collected daily, weighed and placed in labelled plastic bags and stored in a freezer at $-18^{\circ} \mathrm{C}$. After the collection period, fecal samples were thawed, homogenized, weighed on a digital scale and a composite sample $(20 \%$ by total weight of feces) of that collected from each experimental unit was removed. Composite samples were dried in a forced ventilation oven $\left(55^{\circ} \mathrm{C}\right)$, ground in a Wiley type grinder mill and stored in polyethylene pots for analysis of dry matter $(\mathrm{DM})$, organic matter $(\mathrm{OM})$, mineral matter, gross energy (GE), and crude protein (CP). Analyses were carried out at the Unioeste's Animal Nutrition Laboratory (LANA/Unioeste).

Urine was collected daily in plastic buckets containing 20 $\mathrm{mL}$ of 1:1 $\mathrm{HCl}$ to avoid nitrogen volatilization and bacterial proliferation. An aliquot ( $10 \%$ by total volume of urine) was collected daily in polyethylene terephthalate bottles and frozen at $-18^{\circ} \mathrm{C}$. Subsequently, these samples were homogenized and aliquots taken for the determination of GE. All analyses of feed, urine and feces were performed following the procedures previously reported [12].

Coefficients of apparent digestibility, values of nutrients and digestible energy, nitrogen and protein balance The digestibility coefficient of DM, CP, and GE were calculated according to published procedures [13]. The $\mathrm{N}$ content of diets, feces and urine samples was analyzed using the Kjeldahl method. The $\mathrm{N}$ intake, $\mathrm{N}$ excretion (feces and urine), $\mathrm{N}$ absorbed, $\mathrm{N}$ retention, $\mathrm{N}$ retention/ $\mathrm{N}$ intake, $\mathrm{N}$ retention/ $\mathrm{N}$ absorbed, and total $\mathrm{N}$ excretion were then determined.

Quantities of crude protein consumed, crude protein excreted in feces and excreted in urine were obtained by multiplying protein concentrations by the amount of consumed feed, or feces and urine excreted, respectively. From these values, the retained $\mathrm{CP}$, net protein utilization and the biological value of dietary protein, were determined according to a previous study [14].

\section{Statistical analysis}

Before evaluating the results using analysis of variance (ANOVA), the standardized residues analysis of Student (RStudent) was performed to identify outliers. The criterion adopted for identification of outliers was based on a normal distribution curve; values of RStudent greater than or equal to three standard deviations were considered as influential. The normality of the experimental errors and the homogeneity of variances between the treatments for the several variables were previously evaluated using the Shapiro-Wilk and Levine tests, respectively. All parameters had normal distribution and homogeneity.

The statistical model used for the digestibility coefficients and digestible nutrients of the feed was $\mathrm{Y}_{\mathrm{ij}}=\mathrm{m}+\mathrm{T}_{\mathrm{i}}+\mathrm{b}_{\mathrm{j}}+\varepsilon_{\mathrm{ij}}$, wherein: $Y_{i j}=$ observation of the dependent variable in each plot, measured in the $\mathrm{i}$-th protein source, at the $\mathrm{j}$-th block and in $\mathrm{k}$-th replication; $\mathrm{m}=$ effect of the overall mean; $\mathrm{T}_{\mathrm{i}}=$ effect of classes of protein sources, for $i=(1,2$, and 3$) ; b_{j}=$ block effect, for $\mathrm{j}=(1$ and 2$) ; \varepsilon_{\mathrm{ij}}=$ random errors of the plots associated with level $i$, to the block $j$ and replication $k$, independents, homoscedastic and with normal distribution.

The effects of the treatment classes about the dependent variables were verified using ANOVA. The comparisons between treatment averages were performed with Tukey's test, with a 5\% level of significance in all statistical analyses, using SAS software (SAS Inst. Inc. Cary, NC, USA).

For the performance characteristics, the statistical model used was $\mathrm{Y}_{\mathrm{ijk}}=\mathrm{m}+\mathrm{P}_{\mathrm{i}}+\mathrm{S}_{\mathrm{j}}+\mathrm{PS}_{\mathrm{ij}}+\beta\left(\mathrm{X}_{\mathrm{ijk}}-\overline{\mathrm{X}} \ldots\right)+\varepsilon_{\mathrm{ijk}}$. For plasma concentrations of urea and glucose, the statistical model did not include the covariate effect. The effects of the factors included in the model are represented by:

$\mathrm{Y}_{\mathrm{i} \mathrm{k}}=$ average observation of the dependent variable in each plot, measured in the $\mathrm{i}$-th protein source, in the $\mathrm{j}$-th sex class and in the $\mathrm{k}$-th replication; $\mathrm{m}=$ effect of the overall mean; $\mathrm{P}_{\mathrm{i}}$ $=$ effect of class of protein source, for $\mathrm{i}=(1,2$, and 3$) ; \mathrm{S}_{\mathrm{j}}=$ effect of sex classes, for $\mathrm{j}=(1$ and 2$) ; \mathrm{PS}_{\mathrm{ij}}=$ effect of interaction between the $i$-th class of protein source and the $j$-th sex class; $\beta=$ regression coefficient of $Y$ about $X ; X_{i j k}=$ average observation of the covariate (initial $\mathrm{BW}$ ) in each plot, measured in $\mathrm{i}$-th protein class, in $\mathrm{j}$-th sex class and in $\mathrm{k}$-th replicate; $\overline{\mathrm{X}}$... = overall average for the covariate $\mathrm{X} ; \varepsilon_{\mathrm{ijk}}=$ random error of the plot associated with level $\mathrm{i}$, class $\mathrm{j}$, and replication $\mathrm{k}$.

The effects of protein source, sex and interaction between classes of protein source and sex on the dependent variables were determined using analysis of covariance for the performance characteristics. Comparisons between averages of minimum squares (lsmeans), related to the effect of sex, protein source and blood parameters were performed using Tukey's test at the $5 \%$ probability level. Statistical analyses were performed using the "Proc Univariate" and "General Linear Models" procedures of the SAS software (SAS Inst. Inc. Cary, NC, USA). All data are presented as means with pooled standard error of the mean.

\section{Growth performance}

The animals received feed and water ad libitum throughout the experimental period. All the piglets received a pre-weaning feed to reduce weaning stress. Leftover feed was collected, 
weighed and discounted from feed supplied to calculate average daily feed intake (ADFI, $\mathrm{kg} / \mathrm{d}$ ). The combined weight of the animals recorded on an electronic scale (Rinnert brand, capacity of $1,000 \mathrm{~kg}$ ) was registered at the beginning and end of each experimental phase. Weights were: 6.88 to $10.02 \mathrm{~kg}$ for pre-starter I (27 to 40 days of age), 10.03 to $13.08 \mathrm{~kg}$ for pre-starter II (41 to 50 days of age) and 13.09 to $21.28 \mathrm{~kg}$ for starter (51 to 65 days of age). Based on these data, average values were determined for ADFI, daily weight gain (DWG, $\mathrm{kg} / \mathrm{d}$ ), and gain to feed ratio (G:F).

\section{Blood parameters}

Urea and glucose were determined with an automated biochemical analyzer (model Flexor EL 200; ELITech Latin America, Brazil), using specific ELITech kits (Clinical Systems, Brazil).

\section{RESULTS AND DISCUSSION}

\section{Coefficients of apparent digestibility, values of nutrients and digestible energy}

No differences were observed between the treatments for the apparent digestibility coefficients, and digestible nutrients (DN) of DM, OM, and DE. However, there was difference $(\mathrm{p}<0.05)$ between the treatments for the digestible protein (Table 3 ).

Bertol and Ludke [15] reported that the type and processing intensity involved in production of SBM may lead to great differences in digestibility coefficients. In the same study, the authors reported apparent dry matter digestibility coefficient (ADMDC) of $86.58 \%$ and digestible energy (DE) of $3,515 \mathrm{kcal} / \mathrm{kg}$ with diets containing $70 \%$ reference diet and $30 \%$ SPC. For diets with $70 \%$ of the reference diet and $30 \%$ SBM, of which the CP values were $44.5 \%$ and $46.5 \%$, these results were $87.09 \%$ and $87.70 \%$ for ADMDC, 3,387 and

\section{$3,443 \mathrm{kcal} / \mathrm{kg}$ DE, respectively.}

The soybean by-product extrusion process improves $\mathrm{N}$ digestibility, reduces the concentration of trypsin inhibitors and decreases the antigenic properties of these by-products, resulting in better digestibility and reduced potential for immune reaction to soybean proteins [16]. It is noteworthy that, with increasing age, there is an increase in the digestibility coefficient of some nutrients, including protein and ether extract, which is more accentuated in less digestible diets [17].

Although the values of digestibility coefficient of CP (DCCP) varied from $86.65 \%$ to $88.17 \%$, differences were not obtained between the protein sources. The DCCP of SPC was practically analogous to $87.57 \%$ obtained by Bertol and Ludke [15]. In addition, the authors reported an DCCP value of 85.91\% in one experiment (reference diet - 70\% and 30\% of SBM with $44.5 \%$ of $\mathrm{PB}$ ), which was slightly lower than that found in this study $(86.12 \%)$. Studies of the digestibility of FM in pigs are scarce.

The suitable processing of soybean products increases protein breakdown, with greater activity of digestive enzymes, while super processing decreases nutritional value. On the other hand, the lack of heating during processing is also harmful, because the soybean contains anti-nutritional factors interfere with the digestive process [18]. By conjecture, thermal processing of SPC may not have been enough to deactivate the anti-nutritional factors, impairing the availability of amino acids and contributing to the lower digestible protein value in relation to the other experimental diets (Table 3).

The variation observed for $\mathrm{DN}$ in relation to DM (\%) for the diet containing FM was 2.3 percentage units less than the study of Sulabo et al [6], in which the value was $85.93 \%$. Corroborating these values, Rojas and Stein [19] found greater values in their investigation (88.53\%). The digestible DM (\%) for the other treatments were discrepant to those determined

Table 3. Coefficients of apparent digestibility, values of nutrients and digestible energy of piglets in starter phase in Exp 1

\begin{tabular}{|c|c|c|c|c|c|}
\hline \multirow{2}{*}{ Item } & \multicolumn{3}{|c|}{ Treatments ${ }^{1)}$} & \multirow{2}{*}{ SEM } & \multirow{2}{*}{ p-value } \\
\hline & FM & SPC & SBM & & \\
\hline \multicolumn{6}{|c|}{ Coefficients of apparent digestibility } \\
\hline Dry matter (\%) & 85.9 & 87.4 & 85.4 & 0.46 & 0.185 \\
\hline Crude protein (\%) & 86.9 & 88.1 & 86.6 & 0.50 & 0.490 \\
\hline Organic matter (\%) & 88.2 & 89.7 & 87.9 & 0.40 & 0.175 \\
\hline Gross energy (\%) & 87.3 & 88.6 & 87.3 & 0.40 & 0.310 \\
\hline \multicolumn{6}{|c|}{ Values of nutrients and digestible energy } \\
\hline Dry matter (\%) & 83.6 & 84.8 & 82.6 & 0.45 & 0.169 \\
\hline Digestible protein (\%) & $17.8^{\mathrm{a}}$ & $16.7^{b}$ & $18.1^{\mathrm{a}}$ & 0.16 & $<0.001$ \\
\hline Organic matter (\%) & 81.6 & 82.5 & 80.8 & 0.37 & 0.167 \\
\hline Digestible energy (kcal/kg) & 3,810 & 3,842 & 3,851 & 17.05 & 0.606 \\
\hline
\end{tabular}

SEM, pooled standard error of the means.

1) FM, fish meal; SPC, soybean protein concentrate; SBM, soybean meal $(n=8)$.

2) Protein sources (diets) effect.

a,b Values followed by different lowercase letters, in row, differ according to Tukey's test, at 5\% probability level. 
by Bertol and Ludke [15], for SPC with 62.44\% CP (90.84\%) and SBM (88.01\% and $89.58 \%), 44.5 \%$ and $46.5 \%$ CP, respectively.

Oliveira and Stein [4] reported that the increase and improvement in $\mathrm{DE}$ concentrations and metabolizable energy (ME) in barrows (BW of $13.94 \pm 1.34 \mathrm{~kg}$ ) fed with SPC compared to those receiving a diet containing SBM was due to the process used to remove carbohydrates, such as oligosaccharides. These results are linked to the fact that pigs do not secrete $\beta$-galactosidase, an enzyme necessary for the hydrolysis of raffinose and stachyose, therefore these are not enzymatically digested in the small intestine. The removal of oligosaccharides from SPC resulted in greater concentrations of $\mathrm{CP}$ and greater concentrations of DE.

Rojas and Stein [19] determined the concentrations of DE and ME in pigs fed with fermented soybean meal (FSM), conventional soybean meal (CSM) and FM and obtained values consistent with those in this study for DE of FM $(3,827 \mathrm{kcal} /$ $\mathrm{kg})$, but not for CSM (4,553 kcal/kg). The authors considered that this may be a consequence of a greater percentage of ash in the FM used. In addition, the concentration of CP and DE in FM compared with FSM and CSM is most likely due to amino acid composition. However, the results indicate that the amino acids and GE of FM are poorly digested, and consequently the DE and ME were lower in FM than in FSM. This finding is similar with the result of this study when compared to protein sources of vegetable origin.

\section{Nitrogen and protein balance}

With respect to the nitrogen and protein balance in piglets, the difference for variable total nitrogen excretion (TNE, $\mathrm{g} / \mathrm{kg}$ $\left.\mathrm{BW}^{0.75} / \mathrm{d}\right)$ was significant $(\mathrm{p}<0.05)$. There was no effect of treatment on the other variables (Table 4 ).

Dourmad et al [20] reported that approximately $66.66 \%$ of ingested $\mathrm{N}$ is excreted in pigs. Thus, the increase in use of protein compounds decreases urea synthesis, and coincidentally $\mathrm{N}$ retention must be maximized in animals fed amino acid balanced feeds. It is possible that the control diet promoted a greater catabolism of the amino acid molecules, consequently the amount of $\mathrm{N}$ in feces and urine was numerically greater, which caused a difference in TNE $\left(\mathrm{g} / \mathrm{kg} \mathrm{BW}^{0.75} / \mathrm{d}\right)$, since both variables are used to determine absorbed and retained $\mathrm{N}$.

Bertechini [21] claims that $\mathrm{N}$ excretion commonly occurs at a basal ration, being influenced by two situations: process of gluconeogenesis (fasting metabolism) and when there is excessive intake of protein. Finally, it is acceptable that ingested $\mathrm{N}$ was not influenced significantly by the treatments, from the results of $\mathrm{N}$ intake $(27.09,26.44$, and $28.57 \mathrm{~g} / \mathrm{d}$; Table 4$)$ which supports the author's explanation about excretion of $\mathrm{N}$.

According to Dourmad et al [20], the reduction in urinary $\mathrm{N}$ elimination results from the decrease in the amount of $\mathrm{N}$ absorbed through of the intestine and the increase in the use of $\mathrm{N}$. The lack of effect of protein sources on the crude protein intake can be correlated to the absence of significance for the variable ingested $\mathrm{N}$, considering that both are interconnected [22]. The net protein utilization of $64.62 \%$ to $67.22 \%$ in the current study were similar to $65.5 \%$ and $60.8 \%$ obtained by Oliveira et al [23], who worked with growing pigs and concentrations of $12 \%$ and $14 \%$ of $\mathrm{CP}$ in feeds.

Table 4. Nitrogen $(\mathrm{N})$ and protein balance in entire male piglets in starter phase fed with different protein sources in Exp. 1

\begin{tabular}{|c|c|c|c|c|c|}
\hline \multirow{2}{*}{ Item ${ }^{1)}$} & \multicolumn{3}{|c|}{ Treatments $^{2)}$} & \multirow{2}{*}{ SEM } & \multirow{2}{*}{$p$-value ${ }^{3}$} \\
\hline & $\mathrm{FM}$ & SPC & SBM & & \\
\hline $\mathrm{N}$ intake (g/d) & 27.09 & 26.44 & 28.57 & 1.38 & 0.772 \\
\hline N intake $\left(\mathrm{g} / \mathrm{kg} \mathrm{BW} \mathrm{W}^{0.75} / \mathrm{d}\right)$ & 2.41 & 2.30 & 2.52 & 0.07 & 0.453 \\
\hline$N$ fecal $(g / d)$ & 3.51 & 3.20 & 3.98 & 0.27 & 0.526 \\
\hline $\mathrm{N}$ fecal (g/kg BW.0.75/d) & 0.31 & 0.27 & 0.34 & 0.01 & 0.333 \\
\hline N urine $(g / d)$ & 5.39 & 5.42 & 5.98 & 0.30 & 0.610 \\
\hline $\mathrm{N}$ urine $\left(\mathrm{g} / \mathrm{kg} B W^{0.75} / \mathrm{d}\right)$ & 0.48 & 0.47 & 0.54 & 0.02 & 0.242 \\
\hline$N$ absorbed (g/d) & 23.57 & 23.23 & 24.14 & 1.14 & 0.894 \\
\hline $\mathrm{N}$ absorbed $\left(\mathrm{g} / \mathrm{kg} \mathrm{BW} \mathrm{W}^{0.75} / \mathrm{d}\right)$ & 2.09 & 2.03 & 2.16 & 0.05 & 0.582 \\
\hline$N$ retained $(\mathrm{g} / \mathrm{d})$ & 18.17 & 17.80 & 18.16 & 0.96 & 0.961 \\
\hline $\mathrm{N}$ retained $\left(\mathrm{g} / \mathrm{kg} \mathrm{BW} W^{0.75} / \mathrm{d}\right)$ & 1.61 & 1.55 & 1.61 & 0.05 & 0.886 \\
\hline $\mathrm{N}$ retained/intake (\%) & 66.80 & 67.22 & 64.62 & 0.79 & 0.968 \\
\hline $\mathrm{N}$ retained/absorbed (\%) & 76.80 & 76.30 & 74.72 & 0.99 & 0.692 \\
\hline Total N excretion (g/d) & 8.91 & 8.63 & 10.02 & 0.49 & 0.468 \\
\hline Total N excretion (g/kg BW $\left.{ }^{0.75} / \mathrm{d}\right)$ & $0.79^{b}$ & $0.75^{b}$ & $0.88^{\mathrm{a}}$ & 0.02 & 0.049 \\
\hline
\end{tabular}

SEM, pooled standard error of the means; BW, body weight.

1) $\mathrm{CP}=6.25 \times \mathrm{N}$.

2) FM, fish meal; SPC, soybean protein concentrate; SBM, soybean meal $(n=8)$.

${ }^{3)}$ Protein sources (diets) effect.

a,b Values followed by different lowercase letters, in row, differ according to Tukey's test, at 5\% probability level. 


\section{Growth performance}

All the piglets remained healthy throughout the duration of the experiment period. There was a significant effect of interaction $(p<0.05)$ between sex and protein sources on the ADFI, DWG, and G/F in pre-starter I phase, ADFI in prestarter II phase, FBW in starter phase and ADFI, DWG, and FBW for the total period. In addition, in pre-starter I and starter phases, and total period, there was a difference $(\mathrm{p}<0.05)$ in ADFI between the sexes (Table 5). A significant difference $(p<0.05)$ was obtained between the protein sources in starter phase and total period for ADFI, DWG, and FBW (Table 5).

For the effect of sex within diet, the females presented the highest values in relation to males for all the variables of growth performance during the experiment. In contrast, the effect of diet within sex, there was only difference between males, with male piglets fed with SPC+SBM showing the best results (Table 5).

These data are not consistent with results of other studies because differences in performance result from changes that accompany the sexual development of the animal, which cannot be examined at an early age. Analogous effects of sex on performance were reported by Silva et al [24], in a study of sweetener in drinking water, in which females showed better DWG and ADFI in phases between 30 to $45 \mathrm{~d}$ and 45 to 62 $\mathrm{d}$. The authors argued an assumption that males would over- come the weight gain of the females by the age of slaughter.

These results are pertinent to those obtained in this study (Table 5), where SBM presents some disadvantages for feeding piglets at early age, related to low digestibility and the presence of antigenic proteins, glycinin and $\beta$-conglycinin. These anti-nutritional properties cause changes in intestinal mucosa, and, consequently, in growth rate of piglets after weaning [3] by reducing the absorptive and digestive capacity of the gastrointestinal tract.

Similarly, Bertol et al [3] tested soybean by-products on the SPC for piglets weaned at 21 days of age and reported that the partial replacement of SBM by any soybean processed sources improved the growth performance.

It is possible that the protein quality of the studied sources caused differences in final weigh, due the physiological and biochemical changes of functions of the gastrointestinal tract, causing a reduction in growth performance because of the degradation of tissue protein. Bertechini [21] argues that the composition of protein sources can lead to amino acid imbalance that does not meet metabolic requirements. As a result, the intake of an unbalanced diet compromises at the decrease of consumption and growth retardation.

\section{Blood parameters}

There was no interaction between blood parameters, urea and

Table 5. Growth performance of piglets fed with different protein sources in nursery phase in Exp 2

\begin{tabular}{|c|c|c|c|c|c|c|c|c|c|}
\hline \multirow{2}{*}{ Item } & \multicolumn{3}{|c|}{ Protein sources $^{1)}$} & \multicolumn{2}{|c|}{ Sex } & \multirow{2}{*}{ SEM } & \multicolumn{3}{|c|}{ p-value ${ }^{2)}$} \\
\hline & FM & SPC & SBM & Male & Female & & Diets & Sex & Diets $x$ sex \\
\hline \multicolumn{10}{|c|}{ Pre-starter I phase (6.88 to $10.02 \mathrm{~kg}$ ) } \\
\hline ADFI & 0.27 & 0.28 & 0.27 & $0.27^{b}$ & $0.28^{\mathrm{a}}$ & 0.003 & 0.478 & 0.035 & 0.015 \\
\hline DWG & 0.21 & 0.22 & 0.21 & 0.21 & 0.21 & 0.005 & 0.510 & 0.534 & 0.004 \\
\hline $\mathrm{G}: \mathrm{F}$ & 0.76 & 0.79 & 0.77 & 0.78 & 0.77 & 0.01 & 0.741 & 0.685 & 0.042 \\
\hline FBW & 10.31 & 10.19 & 9.59 & 9.98 & 10.07 & 0.15 & 0.468 & 0.335 & 0.282 \\
\hline \multicolumn{10}{|c|}{ Pre-starter II phase (10.03 to $13.08 \mathrm{~kg}$ ) } \\
\hline ADFI & 0.48 & 0.51 & 0.46 & 0.47 & 0.49 & 0.01 & 0.168 & 0.197 & 0.017 \\
\hline DWG & 0.31 & 0.33 & 0.30 & 0.31 & 0.32 & 0.008 & 0.408 & 0.502 & 0.199 \\
\hline $\mathrm{G}: \mathrm{F}$ & 0.66 & 0.66 & 0.65 & 0.66 & 0.65 & 0.01 & 0.963 & 0.668 & 0.391 \\
\hline FBW & 13.36 & 13.33 & 12.57 & 13.05 & 13.13 & 0.17 & 0.447 & 0.526 & 0.093 \\
\hline \multicolumn{10}{|c|}{ Starter phase (13.09 to $21.28 \mathrm{~kg}$ ) } \\
\hline ADFI & $0.79^{\mathrm{ab}}$ & $0.80^{\mathrm{a}}$ & $0.71^{\mathrm{b}}$ & $0.73^{b}$ & $0.80^{\mathrm{a}}$ & 0.01 & 0.017 & $<0.001$ & 0.196 \\
\hline DWG & $0.53^{\mathrm{ab}}$ & $0.56^{\mathrm{a}}$ & $0.48^{b}$ & 0.51 & 0.54 & 0.01 & 0.021 & 0.071 & 0.101 \\
\hline $\mathrm{G}: \mathrm{F}$ & 0.67 & 0.70 & 0.68 & 0.69 & 0.67 & 0.009 & 0.686 & 0.265 & 0.623 \\
\hline FBW & $21.62^{\mathrm{ab}}$ & $22.18^{\mathrm{a}}$ & $20.09^{b}$ & 21.01 & 21.57 & 0.26 & 0.001 & 0.091 & 0.022 \\
\hline \multicolumn{10}{|c|}{ Total period (6.88 to $21.28 \mathrm{~kg}$ ) } \\
\hline ADFI & $0.47^{\mathrm{ab}}$ & $0.49^{\mathrm{a}}$ & $0.44^{b}$ & $0.45^{b}$ & $0.48^{\mathrm{a}}$ & 0.007 & 0.022 & 0.002 & 0.045 \\
\hline DWG & $0.33^{\mathrm{ab}}$ & $0.35^{\mathrm{a}}$ & $0.31^{b}$ & 0.32 & 0.34 & 0.005 & 0.004 & 0.060 & 0.011 \\
\hline $\mathrm{G}: \mathrm{F}$ & 0.71 & 0.72 & 0.71 & 0.72 & 0.70 & 0.005 & 0.398 & 0.134 & 0.372 \\
\hline FBW & $21.62^{\mathrm{ab}}$ & $22.18^{\mathrm{a}}$ & $20.09^{b}$ & 21.01 & 21.57 & 0.26 & 0.001 & 0.091 & 0.022 \\
\hline
\end{tabular}

SEM, pooled standard error of the means; ADFI, average daily feed intake; DWG, daily weight gain; G:F, gain to feed ratio; FBW, final body weight.

1) FM, fish meal; SPC, soybean protein concentrate; SBM, soybean meal.

2) Protein sources (diets) effect; Sex effect; Diets $\times$ sex, interaction between diets and sex.

a,b Lsmeans followed by different lowercase letters, in row, differ according to Tukey's test, at $5 \%$ probability level. 
Table 6. Plasma urea and glucose (mg/dL) in pre-starter II and starter phases according with combinations of protein sources and sex in Exp 2

\begin{tabular}{|c|c|c|c|c|c|c|c|c|c|}
\hline \multirow{2}{*}{ Item } & \multicolumn{3}{|c|}{ Protein sources ${ }^{1)}$} & \multicolumn{2}{|c|}{ Sex } & \multirow{2}{*}{ SEM } & \multicolumn{3}{|c|}{ p-value ${ }^{2)}$} \\
\hline & FM & SPC & SBM & Female & Male & & Diets & Sex & Diets $\times$ sex \\
\hline \multicolumn{10}{|c|}{ Pre-starter II phase (10.03 to $13.08 \mathrm{~kg}$ ) } \\
\hline Urea & $34.02^{b}$ & $33.88^{b}$ & $38.80^{\mathrm{a}}$ & 36.93 & 34.19 & 0.82 & 0.024 & 0.101 & 0.560 \\
\hline Glucose & $103.76^{b}$ & $110.85^{\mathrm{a}}$ & $109.72^{\mathrm{a}}$ & 106.64 & 109.58 & 0.87 & 0.001 & 0.089 & 0.957 \\
\hline \multicolumn{10}{|c|}{ Starter phase (13.09 to $21.28 \mathrm{~kg}$ ) } \\
\hline Urea & $50.33^{b}$ & $53.00^{\mathrm{ab}}$ & $58.23^{\mathrm{a}}$ & $57.11^{\mathrm{a}}$ & $50.60^{b}$ & 1.09 & 0.010 & 0.003 & 0.408 \\
\hline Glucose & 100.4 & 99.80 & 100.66 & 98.81 & 101.76 & 1.13 & 0.949 & 0.218 & 0.063 \\
\hline
\end{tabular}

SEM, pooled standard error of the means.

1) FM, fish meal; SPC, soybean protein concentrate; SBM, soybean meal.

2) Protein sources (diets) effect; Sex effect; Diets $\times$ sex, interaction between diets and sex.

a,b Lsmeans followed by different lowercase letters, in row, differ according to Tukey's test, at 5\% probability level.

glucose and protein sources and sex in pre-starter II and starter phases. However, for both variables in the pre-starter II phase there was a difference $(\mathrm{p}<0.05)$ between the protein sources (Table 6). The values found are close to the established range of 13 to $45 \mathrm{mg} / \mathrm{dL}$ for urea and 65 to $106 \mathrm{mg} / \mathrm{dL}$ for glucose according to the specific ELITech kits (ELITech Group, Paris, [Commune Puteaux], France). A difference $(\mathrm{p}<0.05)$ was also obtained between the protein sources and sex in the urea variable during the starter phase (Table 6).

In this context, it is possible that the protein quality of FM and SPC is relatively greater compared with to the control diet (SBM), considering the plasma urea concentration (PUC). It also suggests that the low biological value of the protein is closely related to the catabolism of amino acids [25].

In the growth phase of animals, the nutritional and physiological needs change, as do protein concentrations in feed, until a plateau of protein requirement is established. Notably, in starter phase the pigs showed a significant increase in blood urea concentration in relation to the previous phase. It is possibly due to the composition of the feed in pre-starter II phase, with ingredients that present better quality and digestibility of the $\mathrm{CP}$ generating smaller concentrations of metabolites.

The increase in the activity of enzymes involved in the urea cycle is essential for conversion of ammonia, generated from the oxidative deamination of protein metabolites, to urea. Metabolic pathways for urea synthesis by the liver use energy [26], in which the most commonly used fuel is glucose, a high energy monosaccharide which breaks down inside cells to release stored energy as molecules of adenosine triphosphate. The increase in urea or PUC synthesis could increase the energy expenditure by the liver and concomitantly reduce the glucose that would be destined for other purposes.

It is recognized that sex affects protein metabolism, especially in the starter phase, where $\mathrm{CP}$ concentrations are partially discrepant [9]. Therefore, the increase of the PUC could be caused by increasing protein concentrations in the diet provided to the piglets.

The rate of muscular deposition in entire males was great- er and more accelerated in relation to females, with maturity of protein deposition later, but in greater amount of use of nitrogen compounds (urea) (Table 6).

\section{CONCLUSION}

The use of SBM-based feeds as a conventional protein source and SPC+SBM for pigs in the starter phase affects total excretion of nitrogen and reduces the digestible protein, respectively. The use of SPC+SBM in piglet feed improves growth performance parameters in the starter phase and in the total period and reduces PUCs in the pre-starter II phase compared to the use of SBM-based feeds only. The use of FM+SBM-based feeds for piglets in the pre-starter II phase reduced plasma glucose concentrations compared to the use of SPC+SBM and SBMbased feeds only.

\section{IMPLICATIONS}

Processed soybean products have low trypsin inhibitors, lower concentrations of antigenic proteins and lectin contents. A factor to be considered in the quality of these products is inadequate processing of the raw material, causing a low nutritional value and lower coefficient of digestibility of the ingredients. Fish meal is a protein of high biological value, but its quality depends of the type and species of fish, freshness of the fish before processing and the method used for processing; these factors may result in products with low protein content and excess minerals, which reduce its nutritional value.

\section{CONFLICT OF INTEREST}

We certify that there is no conflict of interest with any financial organization regarding the material discussed in the manuscript. 


\section{ACKNOWLEDGMENTS}

To the company Nutrifarma and to the Agroindustrial Cooperative of Marechal Cândido Rondon (Copagril) for their participation and funding of the research, and to State University of Western Paraná (Unioeste) and the Post-Graduate Program for the research area.

\section{REFERENCES}

1. Nabuurs MJA, Hoogendoorn A, Van Der Molen EJ, Van Osta ALM. Villus height and crypt depth in weaned and unweaned pigs, reared under various circumstances in the Netherlands. Res Vet Sci 1993;55:78-84.

2. Lopes EL, Junqueira OM, Araújo LF, Nunes RDC, Duarte KF. Protein sources and levels in the initial diets for piglets weaned at 21 days of age. Rev Bras Zootec 2004;33(supl. 3): 2292-9.

3. Bertol TM, Mores N, Ludke JV, Franke MR. Soybean proteins processed by different forms in diets for weaned piglets. Rev Bras Zootec 2001;30:150-7.

4. Oliveira MS, Stein HH. Digestibility of energy, amino acids, and phosphorus in a novel source of soy protein concentrate and in soybean meal fed to growing pigs. J Anim Sci 2016;94: 3343-52.

5. Rojas OJ, Stein HH. Effects of replacing fish, chicken, or poultry by-product meal with fermented soybean meal in diets fed to weanling pigs. Rev Colomb Cienc Pec 2015;28:22-41.

6. Sulabo RC, Mathai JK, Usry JL, et al. Nutritional value of dried fermentation biomass, hydrolyzed porcine intestinal mucosa products, and fish meal fed to weanling pigs. J Anim Sci 2013; 91:2802-11.

7. Thomaz MC, Hannas MI, Tucci FM, et al. Different protein sources in piglet feeds on trypsin activity and blood parameters. Braz J Vet Res Anim Sci 2009;46:112-21.

8. Pekas JC. Versatile swine laboratory apparatus for physiologic and metabolic studies. J Anim Sci 1968;27:1303-6.

9. Rostagno HS, Albino LFT, Donzele JL, et al. Brazilian tables for poultry and swine: composition of feedstuffs and nutritional requirements. 3rd ed. Viçosa, MG, Brazil: Universidade Federal de Viçosa; 2011.

10. Cai Y, Zimmerman DR, Ewan RC. Diurnal variation in concentrations of plasma urea nitrogen and amino acids in pigs given free access to feed or fed twice daily. J Nutr 1994;124: 1088-93.

11. Sakomura NK, Rostagno HS. Research methods in monogastric nutrition. Jaboticabal, SP, Brazil: Funep; 2016.
12. Silva DJ, Queiroz AC. Food analysis (chemical and biological methods). 3rd ed. Viçosa, MG, Brazil: Universidade Federal de Viçosa; 2002.

13. Matterson LD, Potter LM, Stutz MW, Singsen EP. The metabolizable energy of feed ingredients for chickens. Res Rep Conn Agric Exp Stn 1965;7:3-11.

14. Adeola O. Digestion and balance techniques in pigs. In: Lewis AJ, Southern LL, editors. Swine nutrition. 2nd ed. Boca Raton, FL, USA: CRC; 2001.

15. Bertol TM, Ludke JV. Determination of energy values and nitrogen balance of some feeds for the young pigs. Rev Bras Zootec 1999;28:1279-87.

16. Friesen KG, Nelssen JL, Goodband RD, Behnke KC, Kats LJ. The effect of moist extrusion of soy products on growth performance and nutrient utilization in the early weaned pig. J Anim Sci 1993;71:2099-109.

17. Noblet J, Shi XS. Effect of body weight on digestive utilization of energy and nutrients of ingredients and diets in pigs. Livest Prod Sci 1994;37:323-38.

18. Swick, RA. US soybean meal: present quality and future trends [Internet]. Bangkok, Thailand: American Soybean Association; 1997 [cited 1998 May 25]. Available from: http://www.pacweb. net.sg/asa

19. Rojas OJ, Stein HH. Concentration of digestible, metabolizable, and net energy and digestibility of energy and nutrients in fermented soybean meal, conventional soybean meal, and fish meal fed to weanling pigs. J Anim Sci 2013;91:4397-405.

20. Dourmad JY, Seve B, Latimier P, et al. Nitrogen consumption, utilization and losses in pig production in France, The Netherlands and Denmark. Livest Prod Sci 1999;58:261-4.

21. Bertechini AG. Monogastric nutrition. 2nd ed. Lavras, MG, Brazil: Editora UFLA; 2012.

22. Castilha LD, Pozza PC, Nunes RV, et al. Nitrogen balance of barrows $(15-30 \mathrm{~kg}$ ) fed low protein and different digestible isoleucine levels. Arch Zootec 2013;62:623-6.

23. Oliveira V, Fialho ET, Lima JAF, Bertechini AG, De Freitas RTF. Low crude protein diets on the nitrogen and energy metabolism of growing pig. Ciênc Agrotec 2005;29:866-74.

24. Silva CAD, Rocha FL, Machado GS, et al. Sweetener in the drinking water and effects on performance and on the development of intestinal mucosa for piglets subject to segregated early weaned. Rev Bras Zootec 2000;29:1770-6.

25. Allen PC, Danforth HD, Levander OA. Diets high in n-3 fatty acids reduce cecal lesion scores in chickens infected with Eimeria tenella. Poult Sci 1996;75:179-85.

26. Eisemann JH, Nienaber JA. Tissue and whole-body oxygen uptake in fed and fasted steers. Br J Nutr 1990;64:399-411. 